Article

\title{
Partnership-Based Supply Chain Collaboration: Impact on Commitment, Innovation, and Firm Performance
}

\author{
Nina Shin ${ }^{1}$, Sun Hyun Park ${ }^{2}$ and Sangwook Park ${ }^{2, *}$ \\ 1 College of Business Administration, Sejong University, Seoul 05006, Korea; ninashin@sejong.ac.kr \\ 2 College of Business Administration, Seoul National University, Seoul 08826, Korea; sunpark@snu.ac.kr \\ * Correspondence: sangpark@snu.ac.kr; Tel.: +82-2-880-5762
}

Received: 10 December 2018; Accepted: 14 January 2019; Published: 16 January 2019

check for updates

\begin{abstract}
With increasing numbers of nodes and links in supply network relationships, understanding partnership management and the required level of collaboration is important for sustainable supply network alignment. This study explores the impact of partnership orientation on partnership commitment and firm performance using a model based on social capital theory and resource dependence theory. It aims to understand the appropriate partnership orientation for the desired level of commitment and firm performance, including innovation, operational, and financial performance. Using a survey of 423 respondents representing three different partnership structure types (supplier, buyer, and parallel-aligned firms' perspectives), the relationship between partnership orientation and commitment in enhancing firm performance is investigated using structural equation modeling. Additional analysis identifies the moderating role of commitment and investment exchange on performance. The findings show that positive relationships between both investment and contractual-based partnership orientation positively contribute to partnership commitment, but the direct association between partnership commitment and firm performance type varies by partnership structure. Furthermore, (i) investment exchange level moderates the relationship between commitment and innovation and operational performance regardless of partnership structure type, (ii) negative investment exchange signals higher firm performance from the buyer firm's perspective, and (iii) positive investment exchange is absolutely necessary for financial performance from the supplier firm's perspective.
\end{abstract}

Keywords: supply chain collaboration; partnership management; sustainable innovation; firm performance

\section{Introduction}

With increasing numbers of nodes and links in supply network relationships, understanding partnership management and the required level of collaboration is important for sustainable supply network alignment [1,2]. Supply chain collaboration represents various independent firms working collaboratively to design and arrange supply chain operations [3]. Successful collaboration is expected to generate benefits for both a firm and its partner firm [4]. In anticipation of "digitalized supply chains of the future" (Supply Chain Management (SCM) 4.0) facilitating globalization and sustaining relationships with alternative suppliers, research on partnership management from supplier, buyer, and parallel-aligned (or competing) firms' perspectives continues to multiply [5-7].

A key factor in supply chain partnership development is acknowledging the role of collaborative relationship [8]. To increase the collaboration benefit, existing studies sought various antecedents, such as collaborative awareness [5], collaborative culture and technology-driven inter-organizational 
systems [9], and supplier-buyer cooperation [10]. Based on social capital theory, which emphasizes the importance of relational resources, such as relational capital, cognitive capital, and structural capital, social capital was emphasized as the relational glue that contributes to a collaborative behavioral outcome [11]. Specifically, we are interested in the structural capital part of social capital, which can turn into a positive behavioral outcome, such as sustainable commitment through appropriate partnership. Consequently, two key antecedents of partnership commitment can be viewed from two different angles. How much time and resources are a firm and its partner firm willing to invest for their partnership sustainability? How strictly should practitioners require partnership involvement and performance through a legal contract?

In addition to the investigation of means to improve positive behavioral outcome, such as partnership commitment, researchers were warned by the previous literature regarding the dark side of a social capital-driven outcome [12]. Villena et al. [12] found that either too little or too much social capital could hurt performance. However, a successful goal alignment between two partners would produce a sense that the firms were "in this together", thereby creating mutual interest in the overall supply chain success [5]. Sustainable and strategic partnership developed based on joint efforts in planning and information sharing provides a foundation for trust, which can lead to mutual success and improvement $[13,14]$. In conclusion, partnership commitment is a delicate behavioral antecedent that must be examined carefully and in-depth for its potential positive and negative associations with firm performance.

The impact of collaborative relationship extends to the innovation context as well. To create value through sustainable innovation, identification of business models and clear understanding of an innovation network is required [15]. An innovation network is composed of various innovation actors who are either direct or indirect participant of business model. A sustainable innovation market is dependent on the interaction among these participants, and scholars emphasized the need of collaboration-based partnership activities for a successful marketing of sustainable innovation $[15,16]$. For example, Lin et al. [17] noted that that sustainable product innovation decisions should strategically incorporate collective knowledge about market demand characteristics. A high level of market demand knowledge can provide specific research and development (R\&D) quality, which leads to distinct innovation and, ultimately, higher firm performance. Similarly, Kushwaha and Sharma [18] emphasized the need for a green supply chain management initiative as it can bolster higher firm performance in the long run. For a connected network to collectively achieve environmental compliance and improve firm performance, a clear understanding of the orientation and depth of partnership is required.

Based on the direct associations between the presence and depth of partnership and the three types of firm performance (innovation, operational, and financial), this study further investigates partnership structure type (parallel-aligned, supplier, or buyer firms) to obtain a better understanding of various firms' perspectives. The various partnership structure types remain largely unexplored using a single model in the extant literature [19]. To offer a more complete view of strategic partnership management and its impact on firm performance for SCM sustainability, different levels of social capital must be examined across the relationship. This study aims to fill this gap in the literature. For practitioners, this approach offers an important implication, as it explores the differential effect of partnership orientation and commitment on firm performance. Managers would be able to better evaluate and allocate resources for an expected level of performance gain while sustaining a supply chain (SC) collaborative relationship.

The objective of this study was to explore the impact of partnership orientation on partnership commitment and firm performance. Based on a theoretically driven model, the research aimed to help both researchers and business practitioners to gain a deeper understanding of appropriate partnership orientation for the desired level of commitment and firm performance, including innovation, operational, and financial performance. Using a survey of 423 respondents representing various partnership structure types, the research aimed to develop reliable and valid instruments, and to perform structural equation modeling for the empirical findings. 


\section{Theoretical Background and Hypotheses}

\subsection{Social Capital and Resource Dependence Theories}

Social capital theory (SCT) posits that the nature of social capital can be transformed into a relational resource, such as relational capital, cognitive capital, and structural capital [20]. With an increasing degree of complexity embedded in a modern supply chain network relationship, both practitioners and researchers are on a quest to investigate the relationship between social capital and firm performance. For example, Krause et al. [21] examined how a buying firm's commitment to a long-term relationship, cognitive capital (goals and values), structural capital (information sharing, supplier evaluation, and supplier development), and relational capital (length of relationship, buyer dependency, and supplier dependency) are related to the buying firm's performance improvements (cost improvements, quality, delivery, and flexibility improvements). Specifically, from a dyadic relationship perspective, Peng et al. [11] defined social capital as the "relational glue" underpinning effective supply chain relationship in electronic waste (e-wast)e management, and identified that such capital can positively impact both governance parties and a willingness to participate in recycling management. High cooperation, integration, and alignment of the supply chain process are necessary for the digitized supply chains of the future, that is, SCM 4.0 [22]. Thus, the theory is helpful for strategically planning and managing dyadic relationships for desirable social capital-driven performance.

Resource dependence theory (RDT) argues that firms are dependent on both internal and external resources to grow and secure competitiveness [23]. RDT is similar to SCT in that it treats an organization as an open system whose performance depends on the availability and quality of interdependences among supply chain members [24]. RDT is useful for understanding how and to what extent collaborative activities create mutual benefits among supply chain members [25,26]. For example, in the lean manufacturing context, the level of cooperation and coordination among partners is associated with preliminary steps toward lean manufacturing practices, such as reducing the number of suppliers, information sharing, creating communication channels, and the commitment of support [27]. Moreover, RDT was perceived as a useful practical lens in strategic supply management with respect to the level of opportunism (difficulty level of replacing a partner) [28]. For sustainable development of the regional economy, Chen et al. [29] stated that the differences in social network levels (i.e., Guanxi) among different regions influence the frequency of interacting with external resources. By reducing the cost of knowledge access and transfer, entrepreneurial capital can be accumulated through collaborative technological innovation among network connected channels. Therefore, RDT is helpful in identifying the factors that influence the sustainable development of a network formed of various local and global players.

\subsection{Contract- and Investment-Oriented Partnership and Commitment}

Contract-oriented partnership is primarily built on an explicit, formal, and legal contract that typically governs the responsibilities and obligations of interconnected firms [30]. While contractual governance is perceived as a signal for lack of trust and harm to a relational development, it was also found to play a complementary role in other studies. Specifically, when the contract use is a culturally accepted legitimized form of commitment, it is a form of relational governance [31]. As long as the purpose and value of a formal contract is aligned with the coordination level, then the contract is rather received as a higher form of relationship commitment [32].

Investment-oriented partnership is represented by the level of relation-specific investment, such as large capital expenditure based on long-term planning [33]. Relation-specific investments are critical for both the interconnected firm's survival and growth in the industry. The role of significant investments made by both the supplier and buyer was long emphasized for effective value creation [33] and strategic partnerships [34]. Both buyers and suppliers are constantly encouraged to make various types of investments: financial investment, such as R\&D projects and innovations; technological investment in infrastructure equipment; and human capital investment in training and staff development [35]. 
Both contract- and investment-oriented partnership building processes are considered core features of collaborative relationships for interconnected firms. Such mutual efforts are expected to drive changes in the relationship, from a basic structural change to even the quantity and quality of the exchange relationship [36]. For instance, in the information technology (IT) outsourcing relationship context, Reference [37] highlighted the importance of maintaining a balance between contractual and relational governance (vs. overemphasizing either one), while Roehrich and Lewis [38] found that relational governance can produce better performance when accompanied by contractual governance. Long-term interaction offers both the supplier and buyer opportunities to collaborate by revising contract details and/or making relationship-specific investments as part of the effort to sustain partnership commitment [37]. In electronic waste management and recycling governance perspectives, both the structural and cognitive social capitals have positive impacts on governance parties and the willingness to participate in recycling management [11]. Accordingly, the following hypotheses were developed:

Hypothesis 1a (H1a). The higher the level of perceived contract-based partnership is, the higher the level of partnership commitment will be.

Hypothesis $\mathbf{1 b} \mathbf{( H 1 b )}$. The higher the level of perceived investment-based partnership is, the higher the level of partnership commitment will be.

\subsection{Commitment and Innovation, Operational, and Financial Performance}

Partnership commitment is the willingness of a firm to invest financial, physical, or relationship-based resources in a relationship [39]. It is regarded as a useful relational mechanism in controlling opportunism and promoting cooperation in buyer-supplier relationships [40], which can then affect the overall improvement in innovation, financial, and operational performance.

The relationship between commitment-based coordination and innovation performance was expounded traditionally [41]. Innovation is viewed as a social process that determines a firm's innovativeness depending on the type of channel relationship between partners involved [42]. Therefore, a firm's use of collaborative inter-organizational relationships, such as trust and commitment, acts as an inevitable core source of innovation in both the marketing and management literature [43,44]. Specifically, Kleinschmidt et al. [45] noted that organizational factors, such as commitment and firm culture, affect the outcome of new product development. In a new product development context, extensive coordination among inter-firm development teams is emphasized for mitigating unique difficulties through the development of commitment and trust with partner companies [40]. The cooperative adoption of innovation is ignited when the innovation is used by the connected partners and others in the supply network [46]. Thus, the pursuit of innovation through network externalities or critical mass is encouraged [44]. Panayides and Lun [44] concluded that there is strong empirical evidence that diverse forms of social capital contribute more than any other explanatory variable to determining innovation and the radical nature of innovation.

Behavioral antecedents, such as commitment, determine the level of operations, the planning and control process, and the operational performance [47]. Existing studies argue that relational commitment improves communications and facilitates coordination among buyers and suppliers [48]. Wu et al. [49] identified a strong relationship between buyer-supplier commitment and the actual actions of cooperation and collaboration for long-term relationships. The level of commitment, as well as the levels of environmental, social, and cost performance, was emphasized from a resource-based perspective in a sustainability context [50]. Luzzini et al. [50] highlighted the impact of sustainability commitment on the procurement process and overall improved performance. A high level of commitment is expected to provide a basis for sustainable SC outcome through firm performance. Supply chain partners that exhibit high partnership commitment more easily exchange sensitive and proprietary information on business processes [47], supporting Gimenez et al.'s [51] argument 
that cooperative behavior is a prerequisite for operational integration activities, such as planning integration and joint improvement.

The nature of commitment brings stability, which is helpful for establishing social relationships promoting supportive behavior, but it also calls for sacrifice from a social exchange perspective [52]. High commitment does not always necessarily lead to a positive financial outcome, as according to some local-level managers, they might not make commitments without assessing short- and long-term financial outcomes [53]. More interestingly, in a high innovative context, commitment shows complex findings. Yam and Chan [40] (p. 1068) stated that interview respondents noted that "firms would try their best to avoid sharing knowledge if they suspected strong threats of opportunism", signaling a potential negative outcome of excessive partnership commitment. While commitment studies validated the mutual benefits of commitment for both suppliers and buyers in a supply chain relationship, its potential impact on individual financial performance may vary. Accordingly, the following hypotheses are proposed:

Hypothesis 2a (H2a). The higher the level of partnership commitment is, the more innovative the performance will be.

Hypothesis $\mathbf{2} \mathbf{b}(\mathbf{H} \mathbf{2} \mathbf{b})$. The higher the level of partnership commitment is, the more operational the performance will be.

Hypothesis 2c (H2c). The higher the level of partnership commitment is, the lower the financial performance will be.

\subsection{Innovation and Operational and Financial Performance}

Innovation is represented by incremental or radical changes in product, process, and value activities [54], and the degree of its level was defined by a variety of valuable, rare, inimitable, and differentiated products and services [55]. Innovation generally refers to higher firm performance [56] or is at least expected to result in organizational change, which ultimately affects the overall firm performance [44,57].

Damanpour [58] noted that the adoption of innovation contributes to a firm's operational performance, and, according to Panayides and Lun [44], openness to new ideas promotes administrative efficiencies and adoption of new process technologies, leading to supply chain performance improvement. Both technological improvement and supply chain performance (i.e., delivery reliability, responsiveness, and cost reduction) stem from innovations. As a result, innovation performance contributes to a firm's productivity [59], supply chain success [44], and positional and competitive advantage [60].

Innovation-driven technological advances are emphasized for their primary role in the growth of an economy and industry [59]. To compete in the present global economy, firms are required to seek and foster innovation capability. In a sustainability context, green product innovation plays a significant role in both increasing the customer's interest in taking advantage of both cost and environmental protection, and improving overall firm performance $[17,18,29]$. Sustainable innovation, which is strategically driven by the knowledge of market demand, results in green product innovation which cannot be easily copied in other countries, thereby creating higher firm performance [17]. Accordingly, the following hypotheses are proposed:

Hypothesis 3a (H3a). The higher the level of innovation performance is, the higher the operational performance will be.

Hypothesis $\mathbf{3 b} \mathbf{b} \mathbf{H} \mathbf{3} \mathbf{b})$. The higher the level of innovation performance is, the higher the financial performance will be. 


\section{Research Methodology}

\subsection{Sampling and Data Collection}

Supply chain partnership orientation and its consequences were determined by the bilateral relationship between supply chain members. We measured the theoretical constructs from both buyer and suppler firms' viewpoints (Structures B and C). In addition, firms that are collaboratively contracted to supply a finished product or service to a common customer or a final buying firm were represented as parallel-aligned firms (Structure A), as shown in Figure 1.

The theoretical constructs were tested by consulting a nationwide survey organization in three steps: (1) the listing of survey respondents; (2) screening; and (3) conducting the survey. Firstly, a cross-sectional list of more than 1912 professionals with over three years of experience in partnership management was created. A filtering process was used in the second step to remove those without sufficient knowledge of supply chain processes (understanding of product and service flow), or the ability to distinguish buyer-supplier relationships (understanding of the respondent's firm and partner's transaction positioning), and those who were not involved in business transactional activities (no direct experience in collaborating with a partner firm). After the screening process, a stratified sample of 423 respondents (22.1\% response rate) completed an online survey during the third step. Prior to this step, respondents were reminded to provide answers about a specific partnership firm that consisted of the following characteristics: (i) a partner firm that the respondent was directly responsible for, (ii) a partner firm that contributed the majority of revenue to the respondent's firm, (iii) a partner firm that was strategically considered a core partner to the respondent's firm, and (iv) a partner firm currently involved in critical issues, such as technology, delivery, collaboration, and communication. The subjects' characteristics are summarized in Table 1.

Table 1. Statistical information of key features of valid samples.

\begin{tabular}{|c|c|c|c|}
\hline Category & Distribution & Sample Size & Percentage $(\%)$ \\
\hline \multirow{3}{*}{$\begin{array}{l}\text { Partnership structure } \\
\text { type }\end{array}$} & A: Parallel-aligned firm & 153 & 0.36 \\
\hline & B: Buyer firm & 188 & 0.44 \\
\hline & C: Supplier firm & 82 & 0.19 \\
\hline \multirow{13}{*}{ Industry } & Manufacturing & 167 & 0.44 \\
\hline & Construction & 52 & 0.14 \\
\hline & Professional, scientific, and technical services & 30 & 0.08 \\
\hline & Wholesale trade & 22 & 0.06 \\
\hline & Finance and insurance & 18 & 0.05 \\
\hline & Educational services & 18 & 0.05 \\
\hline & Healthcare and social assistance & 16 & 0.04 \\
\hline & Information & 14 & 0.04 \\
\hline & Retail trade & 12 & 0.03 \\
\hline & Transportation and warehousing & 12 & 0.03 \\
\hline & Management of companies and enterprises & 12 & 0.03 \\
\hline & Public administration & 9 & 0.02 \\
\hline & Others & 41 & 0.10 \\
\hline \multirow{5}{*}{$\begin{array}{c}\text { Working experience } \\
\text { years }\end{array}$} & Less than 10 years & 155 & 0.37 \\
\hline & From 10 to 15 years & 141 & 0.33 \\
\hline & From 15 to 20 years & 68 & 0.16 \\
\hline & From 20 to 30 years & 51 & 0.12 \\
\hline & More than 30 years & 8 & 0.02 \\
\hline \multirow{5}{*}{$\begin{array}{c}\text { Partnership management } \\
\text { years }\end{array}$} & Less than 5 years & 124 & 0.29 \\
\hline & From 5 to 10 years & 185 & 0.44 \\
\hline & From 10 to 15 years & 80 & 0.19 \\
\hline & From 15 to 20 years & 23 & 0.05 \\
\hline & More than 20 years & 11 & 0.03 \\
\hline
\end{tabular}




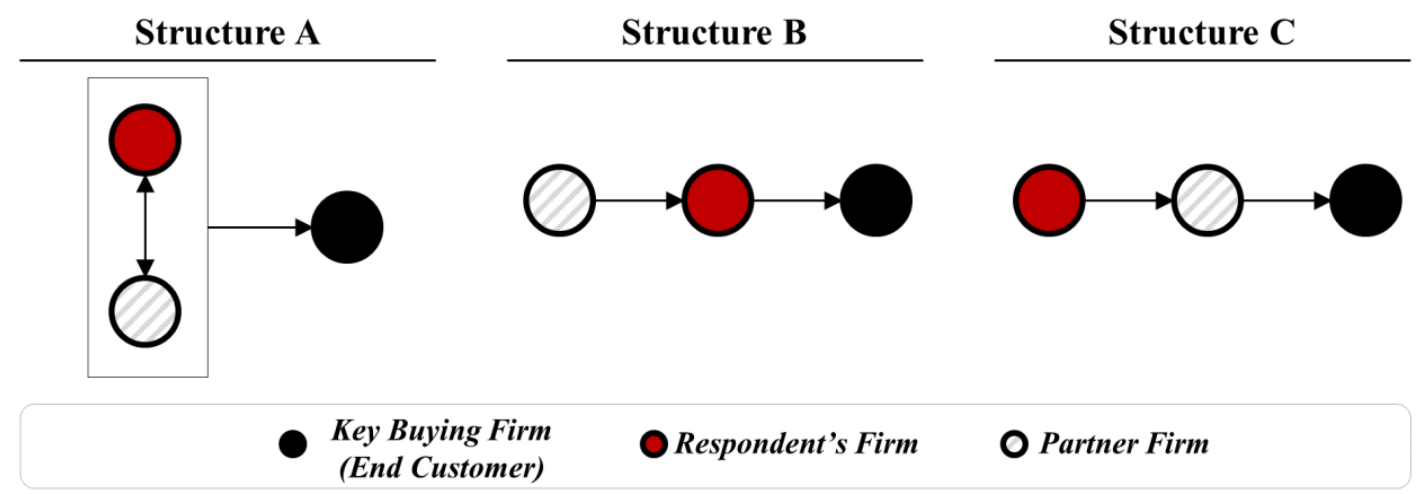

Figure 1. Partnership structure type.

\subsection{Measurement Items}

The initial questionnaire was based on well-established measures in assessment studies (Table 2). Investment-oriented partnership, contract-oriented partnership, and commitment constructs were measured on a seven-point Likert scale (i.e., $1=$ strongly disagree to $7=$ strongly agree) to indicate the response that most closely described the respondent's and partner's firm. Innovation, operational, and financial performance constructs were measured on a seven-point Likert scale (i.e., 1 = extremely worse to $7=$ extremely better) to determine the extent the firm performance changed over the last three years. The initial questionnaire was translated into Korean by a professional language instructor to ensure consistent wording, and was then finalized by 10 experts from different fields (automotive, pharmaceutical, design R\&D, and electronics). The questionnaire was translated back to English to confirm a semantic discrepancy check.

Investment-oriented partnership, an independent construct, was measured with five collective indicators that investigate the level of investment in physical and human assets dedicated by a partner firm [61]. Contract-oriented partnership, an independent construct, was measured with five constructs that capture the severity of the governance mechanism, adopted from Um and Kim [4]. Commitment, a mediator, was measured with three indicators (investment, contractual, and long-term commitment), adopted from Kumar et al. [62]. Innovation performance, operational performance, and financial performance, the dependent variables, were measured with five to seven indicators adopted from Kim [63] and Tomlinson and Fai [64].

\subsection{Validation and Reliability}

Prior to testing the hypotheses, AMOS 24.0 software was used to assess and confirm the validity and reliability of the instrument. Using confirmatory factor analysis, several steps were taken to check (i) unidimensionality and convergent validity, (ii) reliability, and (iii) discriminant validity. The model fit indexes were utilized to evaluate the unidimensionality of each measurement construct. Aligned with Hair et al. [65], we evaluated the normed chi-square $\left(\chi^{2}\right)$, comparative fit index (CFI), Tucker-Lewis index (TLI), and root-mean-square error of approximation (RMSEA) for the model assessment. Evidence of good fit could be determined by the following statistical values: normed- $\chi^{2}$ less than 3.0, CFI greater than 0.70, TLI greater than 0.90, and RMSEA less than 0.10 [65].

The assessment result of the instrument (Table 2) confirmed that all item loadings were statistically significant, ranging from 0.699 to 0.918 and indicating strong convergent validity of the measurement constructs relating to specific latent constructs; the composite reliabilities (CR) of the latent constructs ranged from 0.840 to 0.957 , demonstrating a feasible level of reliability $(>0.70)$ [66]; and the estimates of average variance extracted (AVE) for the constructs were also adequate, ranging from 0.525 to 0.789 $(>0.50)$ [67]. Lastly, the model fit was adequate $\left(\chi^{2}=1054.60 ; d f=419 ; p<0.001 ; \mathrm{CFI}=0.939 ; \mathrm{TLI}=0.93\right.$; RMSEA = 0.06). 
Table 2. Survey instrument and statistical validation.

\begin{tabular}{|c|c|c|c|c|c|}
\hline Latent Variables & & Measurement Variables & Loadings & CR & AVE \\
\hline \multirow{5}{*}{$\begin{array}{l}\text { Investment-oriented } \\
\text { partnership }\end{array}$} & IPART1 & $\begin{array}{l}\text { This partner firm makes significant investments in } \\
\text { resources dedicated to their relationship with us. }\end{array}$ & 0.746 & 0.847 & 0.525 \\
\hline & IPART2 & $\begin{array}{l}\text { We make significant investments in resources } \\
\text { dedicated to our relationship with this partner firm. }\end{array}$ & 0.777 & - & - \\
\hline & IPART3 & $\begin{array}{l}\text { Training our people involves substantial commitments } \\
\text { of time and money for this partner firm. }\end{array}$ & 0.730 & - & - \\
\hline & IPART4 & $\begin{array}{l}\text { This partner firm invests substantial commitments of } \\
\text { time and money to train and operate workshops for } \\
\text { our people }\end{array}$ & 0.698 & - & - \\
\hline & IPART5 & $\begin{array}{l}\text { We make significant investments in resources } \\
\text { dedicated to our relationship with this partner firm. }\end{array}$ & 0.668 & - & - \\
\hline \multirow{5}{*}{$\begin{array}{l}\text { Contract-oriented } \\
\text { partnership }\end{array}$} & CPART1 & $\begin{array}{l}\text { We have a specific, well-defined agreement with this } \\
\text { partner firm }\end{array}$ & 0.815 & 0.908 & 0.664 \\
\hline & CPART2 & $\begin{array}{l}\text { We have customized agreements that detail the } \\
\text { obligations of both parties }\end{array}$ & 0.853 & - & - \\
\hline & CPART3 & $\begin{array}{l}\text { We have detailed contractual agreements specifically } \\
\text { designed with this partner firm }\end{array}$ & 0.814 & - & - \\
\hline & CPART4 & $\begin{array}{l}\text { Most aspects of our relationship are specified in the } \\
\text { contract }\end{array}$ & 0.835 & - & - \\
\hline & CPART5 & $\begin{array}{l}\text { Our contract precisely defines what will happen in } \\
\text { case of unexpected events }\end{array}$ & 0.753 & - & - \\
\hline \multirow{3}{*}{ Commitment } & COMM1 & $\begin{array}{l}\text { We are willing to put more effort and investment in } \\
\text { building our business with the partner. }\end{array}$ & 0.699 & 0.840 & 0.638 \\
\hline & COMM2 & $\begin{array}{l}\text { We want to remain a member of the partner's network } \\
\text { because we genuinely enjoy our relationship with it. }\end{array}$ & 0.871 & - & - \\
\hline & COMM3 & $\begin{array}{l}\text { We expect our relationship with the partner to } \\
\text { continue for a long time. }\end{array}$ & 0.816 & - & - \\
\hline \multirow{5}{*}{$\begin{array}{l}\text { Innovation } \\
\text { performance }\end{array}$} & IPERF1 & Number of new services (contents, items) introduced & 0.786 & 0.915 & 0.682 \\
\hline & $I P E R F 2$ & $\begin{array}{l}\text { Number of changes/improvements to existing } \\
\text { services (contents, items) }\end{array}$ & 0.798 & - & - \\
\hline & IPERF3 & $\begin{array}{l}\text { Number of new equipment/technologies introduced } \\
\text { in the service (contents, items) process }\end{array}$ & 0.835 & - & - \\
\hline & IPERF4 & $\begin{array}{l}\text { New input ideas or materials introduced in the service } \\
\text { (contents, items) process }\end{array}$ & 0.838 & - & - \\
\hline & IPERF5 & $\begin{array}{l}\text { Number of organizational changes/ improvements } \\
\text { made in the service (contents, items) processes }\end{array}$ & 0.869 & - & - \\
\hline \multirow{7}{*}{$\begin{array}{l}\text { Operational } \\
\text { performance }\end{array}$} & OPERF1 & Conformance to specification & 0.782 & 0.928 & 0.649 \\
\hline & OPERF2 & Service quality performance & 0.833 & - & - \\
\hline & OPERF3 & On-time delivery & 0.819 & - & - \\
\hline & OPERF4 & Speed of delivery & 0.744 & - & - \\
\hline & OPERF5 & Volume or capacity flexibility & 0.848 & - & - \\
\hline & OPERF6 & Degree of service, product, contents variety & 0.780 & - & - \\
\hline & OPERF7 & Overall operations cost & 0.827 & - & - \\
\hline \multirow{6}{*}{$\begin{array}{l}\text { Financial } \\
\text { performance }\end{array}$} & FPERF1 & Growth in sales & 0.881 & 0.957 & 0.789 \\
\hline & FPERF2 & Growth in return on sales & 0.905 & - & - \\
\hline & FPERF3 & Growth in profit & 0.912 & - & - \\
\hline & FPERF4 & Growth in market share & 0.839 & - & - \\
\hline & FPERF5 & Return on sales & 0.918 & - & - \\
\hline & FPERF6 & Return on investment & 0.873 & - & - \\
\hline
\end{tabular}

Discriminant validity was assessed by examining whether the square roots of AVE (starred variables on the diagonal in Table 3) were greater than the squared multiple correlation values shown below the diagonal [68]. All correlations satisfied this condition, with the exception of the correlation between innovation performance and operational performance. A chi-square discriminant validity 
test of the innovation and operational performance constructs revealed that these were significantly distinct $(p<0.001)$. In addition, a CFA with two separate constructs $\left(\chi^{2}=174.71 ; d f=45 ; p<0.001\right.$; $\mathrm{CFI}=0.97 ; \mathrm{TLI}=0.96 ; \mathrm{RMSEA}=0.08$ ) had a better fit index than a CFA with two combined constructs $\left(\chi^{2}=710.42 ; d f=54 ; p<0.001 ; \mathrm{CFI}=0.84 ; \mathrm{TLI}=0.80 ; \mathrm{RMSEA}=0.154\right)$. This result implies that the two constructs should be assessed separately.

Table 3. The discriminant measures.

\begin{tabular}{ccccccc}
\hline Constructs & IPART & CPART & COMM & IPERF & OPERF & FPERF \\
\hline Innovation-oriented partnership (IPART) & $0.725^{*}$ & & & & & \\
Contract-oriented partnership (CPART) & 0.500 & $0.815^{*}$ & & & & \\
Partnership commitment (COMM) & 0.521 & 0.530 & $0.799 *$ & & & \\
Innovation performance (IPERF) & 0.482 & 0.569 & 0.621 & $0.826^{*}$ & & $0.805^{*}$ \\
Operational performance (OPERF) & 0.524 & 0.582 & 0.714 & 0.849 & $0.888^{*}$ \\
Financial performance (FPERF) & 0.317 & 0.384 & 0.412 & 0.736 & 0.662 & 0.826 \\
\hline
\end{tabular}

\section{Data Analysis and Results}

\subsection{Hypothesis Test Results}

A structural equation model was used to assess the overall relationships between investment-oriented partnership, contract-oriented partnership, partnership commitment, innovation performance, operational performance, and financial performance. The model showed a good fit with normed $\chi^{2}=2.80, \mathrm{CFI}=0.93, \mathrm{TLI}=0.92$, and RMSEA $=0.065$. From Figure 2 , we can observe that all hypotheses were supported at the $p<0.001$ level with the exception of hypothesis $2 \mathrm{c}(\mathrm{H} 2 \mathrm{c})$.

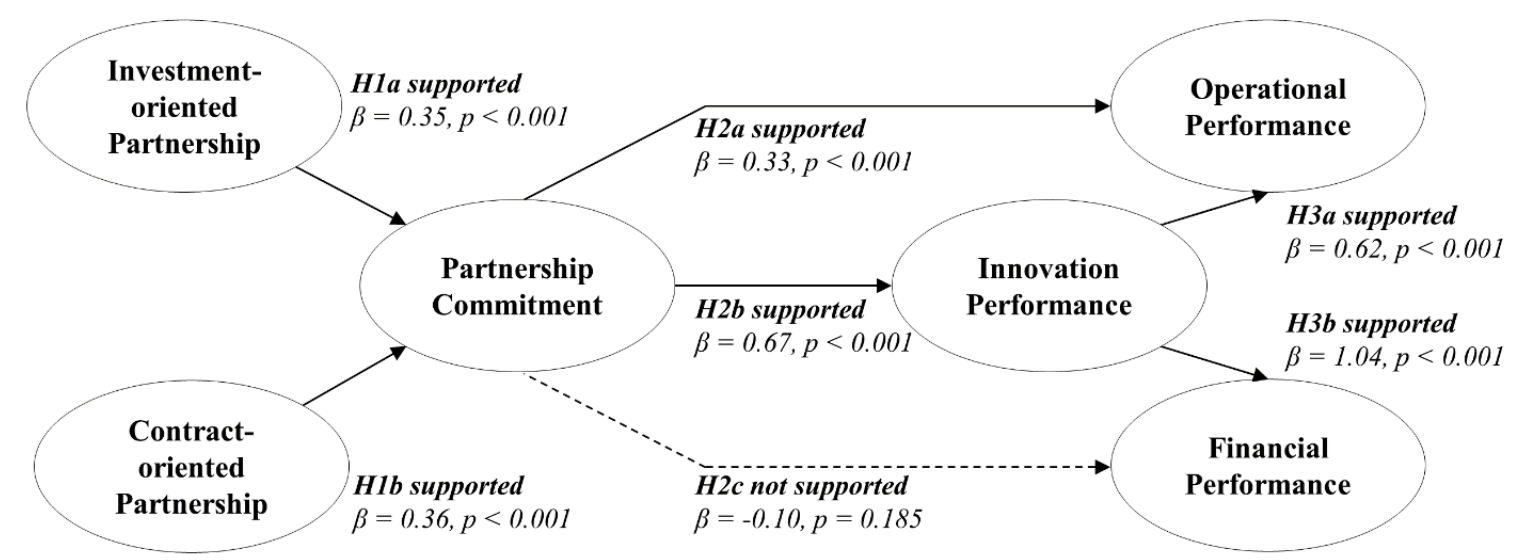

Figure 2. Structural equation model (SEM) result of partnership-based performance improvement model (unstandardized loadings and $p$-value).

For a commitment relationship that is driven by partnership type, the empirical results revealed that higher investment-oriented and contract-oriented partnership leads directly to better commitment ( $\beta=0.35 ; p<0.001$ and $\beta=0.36 ; p<0.001$, respectively), thereby supporting both H1a and H1b. Specifically, contract-oriented partnership had a marginally higher impact than investment-oriented partnership on the level of commitment, with a higher coefficient.

For commitment-performance hypothetical relationships, higher commitment directly affects operational performance $(\beta=0.33 ; p<0.001)$ and innovation performance $(\beta=0.67 ; p<0.001)$, thereby supporting $\mathrm{H} 2 \mathrm{a}$ and $\mathrm{H} 2 \mathrm{~b}$. However, the relationship between commitment and financial performance showed a $p$-value greater than 0.01 and the estimate $\beta$ was almost zero. The absence of influence of commitment on financial performance is further investigated in the next section.

Finally, for the direct effect of innovation performance on operational and financial performance, statistically positive relationships were found ( $\beta=0.62 ; p<0.001$ and $\beta=1.04 ; p<0.001$, respectively). 


\subsection{Structure-Dependent Results}

Further evaluations of hypothesis testing were carried out by the respondent's structure type (A: parallel-aligned firm's perspective, B: buyer firm's perspective, C: supplier firm's perspective), as shown in Table 4. The model fit results showed marginally acceptable fit statistics: (Structure A) normed- $\chi^{2}=1.73, \mathrm{CFI}=0.91$, TLI $=0.91$, and RMSEA $=0.07$; (Structure B) normed- $\chi^{2}=1.62$, $\mathrm{CFI}=0.95, \mathrm{TLI}=0.94$, and RMSEA $=0.06$; and (Structure $\mathrm{C}$ ) normed $\chi^{2}=1.46, \mathrm{CFI}=0.92, \mathrm{TLI}=0.90$, and RMSEA $=0.08$.

Table 4. Structural equation model (SEM) result by partnership structure type (unstandardized loadings).

\begin{tabular}{ccccccc}
\hline \multicolumn{2}{c}{ Hypotheses } & & Structure A & Structure B & Structure C \\
\hline H1a & Investment-Oriented Partnership & $\rightarrow$ & Partnership Commitment & $0.379^{\dagger}$ & $0.358^{\dagger}$ \\
$\mathrm{H} 1 \mathrm{~b}$ & Contract-Oriented Partnership & $\rightarrow$ & Partnership Commitment & $0.342^{\dagger}$ & $0.250^{\ddagger}$ \\
$\mathrm{H} 2 \mathrm{a}$ & Partnership Commitment & $\rightarrow$ & Operational Performance & $0.206^{\dagger}$ & $0.407^{\dagger}$ & $0.274^{\dagger}$ \\
$\mathrm{H} 2 \mathrm{~b}$ & Partnership Commitment & $\rightarrow$ & Innovation Performance & $0.436^{\dagger}$ & $0.834^{\dagger}$ & $0.306^{\dagger}$ \\
$\mathrm{H} 2 \mathrm{c}$ & Partnership Commitment & $\rightarrow$ & Financial Performance & $0.057^{\ddagger}$ & $-0.023^{\ddagger}$ & $-0.487^{\dagger}$ \\
$\mathrm{H} 3 \mathrm{a}$ & Innovation Performance & $\rightarrow$ & Operational Performance & $0.670^{\dagger}$ & $0.522^{\dagger}$ & $0.751^{\dagger}$ \\
$\mathrm{H} 3 \mathrm{~b}$ & Innovation Performance & $\rightarrow$ & Financial Performance & $0.983^{\dagger}$ & $1.006^{\dagger}$ & $1.186^{\dagger}$ \\
\hline
\end{tabular}

NOTE: ${ }^{\dagger}$ significant with $p$-value less than $0.001 ;^{\ddagger}$ statistically insignificant.

A statistically positive relationship between investment-oriented partnership and partnership commitment was found for structures A and B with loadings of 0.379 and 0.358 , respectively, and a $p$-value less than 0.001 , as shown in Table 4 . This finding indicates that an increase in partnership investment can lead to a higher sustainable commitment level from interconnected partners. However, in the case of structure $C$, in which the respondent firm is in a supplier position, the effect of partnership investment on commitment level is insignificant.

Contracted-oriented partnership had significant positive relationships with partnership commitment for structure $\mathrm{A}(\beta=0.342 ; p<0.001)$, structure $\mathrm{B}(\beta=0.407 ; p<0.001)$, and structure $\mathrm{C}$ $(\beta=0.274 ; p<0.001)$. In other words, partnership built on a formal and legal contract had a strong relationship with the level of partnership commitment. Noticeably, contractual-oriented partnership had a higher effect on commitment level than investment-oriented partnership for structure. Moreover, for structure $C$, despite the lack of statistical findings on the effectiveness of partnership investment, the contract-based partnership was found to drive a high partnership commitment.

As hypothesized, the level of partnership commitment is related to the levels of operational and innovation performance. In the order of structures $\mathrm{B}, \mathrm{C}$, and $\mathrm{A}$, the effectiveness of commitment strongly indicated positive outcomes. Specifically, structure B showed a strong result in operational performance $(\beta=0.463, p<0.001)$ and innovation performance $(\beta=0.834, p<0.001)$. Moreover, for all structure types, higher commitment directly affected innovation performance more than it affected operational performance $(\beta=0.436>0.206$ for structure $\mathrm{A}, \beta=0.834>0.463$ for structure $\mathrm{B}$, and $\beta=0.617>0.306$ for structure $C$ ). The most interesting result was that partnership commitment has either an insignificant or even a negative effect on financial performance. This result may indicate that commitment comes at great cost and could negatively affect financial outcome despite an improvement in other types of performance.

Lastly, statistically significant relationships between innovation performance and operational performance and financial performance were found for all structure types. Structure $C$ showed the strongest relationship between innovation and operational performance $(\beta=0.751, p<0.001)$ and financial performance $(\beta=1.186, p<0.001)$.

\subsection{Post Hoc Analysis}

In addition to the proposed model testing, we performed a post hoc analysis to explore the moderating roles of investment-oriented partnership and the relative investment levels between two firms, that is, whether the relationship between partnership commitment and firm performance is 
contingent on a certain level of investment-oriented partnership or the relative level of investment by a respondent firm versus a partnership firm. Hierarchical regression analysis and a supplementary analysis of two-way interaction effects were conducted.

To examine the effect of partnership commitment on firm performance, and the moderating effect of investment-oriented partnership, we developed four models (Table 5): Model 1 served as a reference model, including only control variables; Model 2 added an independent variable (partnership commitment); Model 3 added a moderating variable (investment-oriented partnership); and Model 4 placed the interaction terms. We examined the contribution from Models 1 to 4 based on the significance of the $F$-statistic associated with the change in $R^{2}$. The control variables consisted of partnership structure (i.e., parallel-aligned, buyer, or supplier firm's perspective), length of partnership year (actual numbers were entered), likelihood of recontract, and firm size (actual numbers were entered). F-statistics for all models were found to be significant at a $p$-value of less than 0.001 and, thus, we proceeded with the regression result analysis. For partnership commitment, innovation performance, and financial performance, both the moderator and interaction terms were significantly associated with firm performance ( $\beta=0.697$ (innovation); 0.650 (financial), $p<0.001$ ). While the moderator was not significantly associated with operational performance, the interaction term was found to be significant $(\beta=0.466, p<0.01$ ). Among the control variables, recontract likelihood was negatively associated with all three performance types of firms in Model 4.

To further examine the effect of investment level on partnership commitment and firm performance (i.e., negative moderating effect of investment-oriented partnership on innovation performance and financial performance), we operationalized two investment characteristic groups: a positive investment exchange group, represented by firms whose partnership firms' investment average was higher than that of the respondent firm $(n=71$, distance average $=0.92 \pm 0.47$, distance range between 0.67 and 4.0); and a negative group, comprising firms with higher investment by respondent firms than that by partnership firms $(n=95$, distance average $=-0.98 \pm 0.55$, distance range between -3.67 and -0.67$)$. Table 6 shows that, when investment exchange is positive, noted as $\operatorname{INVX}(+)$, the interaction term (investment-oriented partnership $\times$ commitment) is more significantly associated with innovation performance $(\beta=0.988, p<0.05)$ and operational performance $(\beta=0.715$, $p<0.01$ ) than when investment exchange is negative ( $\beta=0.596$ (innovation) 0.512 (operational), not significant). As shown in Figure 3, the results are illustrated by the plots of the two-way interaction effects, which enabled us to identify the partnership commitment effects on firm performance for two different investment exchange levels for the three different partnership structure types. 
Table 5. Regression results.

\begin{tabular}{|c|c|c|c|c|c|c|c|c|c|c|c|c|}
\hline \multirow{2}{*}{ Dependent Variables } & \multicolumn{4}{|c|}{ Innovation Performance } & \multicolumn{4}{|c|}{ Operational Performance } & \multicolumn{4}{|c|}{ Financial Performance } \\
\hline & Model 1 & Model 2 & Model 3 & Model 4 & Model 1 & Model 2 & Model 3 & Model 4 & Model 1 & Model 2 & Model 3 & Model 4 \\
\hline Control variables & - & - & - & - & - & - & - & - & - & - & - & - \\
\hline Partnership structure & $-0.085 *$ & -0.066 & -0.059 & -0.047 & -0.048 & -0.027 & -0.021 & -0.013 & $-0.085^{*}$ & -0.072 & -0.066 & -0.055 \\
\hline Partnership year & $0.094^{*}$ & 0.048 & 0.036 & 0.037 & 0.080 & 0.027 & 0.017 & 0.018 & -0.057 & $-0.089 *$ & $-0.099 * *$ & $-0.098^{* *}$ \\
\hline Recontract likelihood & $0.122 * *$ & 0.023 & 0.025 & 0.016 & $0.225^{* * *}$ & $0.112 * * *$ & 0.113 & $0.107^{* * *}$ & $0.081 *$ & 0.011 & 0.012 & 0.004 \\
\hline Firm size & $-0.142^{* * *}$ & $-0.131^{* * *}$ & $-0.120 * * *$ & $-0.116^{* * *}$ & $-0.107^{* *}$ & $-0.095^{* *}$ & -0.085 & $-0.082 * *$ & $-0.154^{* * *}$ & $-0.147^{* * *}$ & $-0.138^{* * *}$ & $-0.135^{* * *}$ \\
\hline Main effect & - & - & - & - & - & - & - & - & - & - & - & - \\
\hline Commitment (COMM) & - & $0.487^{* * *}$ & $0.389^{* * *}$ & 0.067 & - & $0.561^{* * *}$ & $0.478^{* * *}$ & $0.262^{* * *}$ & - & $0.348^{* * *}$ & $0.275^{* * *}$ & -0.026 \\
\hline Moderator & - & - & - & - & - & - & - & - & - & - & - & - \\
\hline $\begin{array}{l}\text { Investment-oriented } \\
\text { partnership (IPART) }\end{array}$ & - & - & $0.224^{* * *}$ & $-0.248 *$ & - & - & $0.189 * * *$ & -0.126 & - & - & $0.168^{* * *}$ & $-0.272 *$ \\
\hline Interaction terms & - & - & - & - & - & - & - & - & - & - & - & - \\
\hline $\mathrm{COMM} \times \mathrm{IPART}$ & - & - & - & $0.697^{* * *}$ & - & - & - & $0.466^{* *}$ & - & - & - & $0.650^{* * *}$ \\
\hline$R^{2}$ & 0.060 & 0.284 & 0.323 & 0.344 & 0.082 & 0.378 & 0.406 & 0.415 & 0.040 & 0.154 & 0.176 & 0.194 \\
\hline Change in $R^{2}$ & - & 0.223 & 0.040 & 0.021 & - & 0.296 & 0.028 & 0.009 & - & 0.114 & 0.022 & 0.018 \\
\hline Change in $F$-value & $6.729 * * *$ & $33.008^{* * *}$ & $33.140^{* * *}$ & $31.087^{* * *}$ & $9.326^{* * *}$ & $50.616^{* * *}$ & $47.424^{* * *}$ & $42.124^{* * *}$ & $4.348^{* * *}$ & $15.182^{* * *}$ & $14.859^{* * *}$ & $14.305^{* * *}$ \\
\hline
\end{tabular}

NOTE: the main table contains unstandardized coefficients; ${ }^{*} p<0.10 ;{ }^{* *} p<0.05 ; * * * p<0.01$. 
Table 6. Regression results between negative and positive investment exchange (INVX).

\begin{tabular}{ccccccc}
\hline \multirow{2}{*}{ Dependent Variables } & \multicolumn{2}{c}{ Innovation Performance } & \multicolumn{2}{c}{ Operational Performance } & \multicolumn{2}{c}{ Financial Performance } \\
\cline { 2 - 7 } & INVX (-) & INVX (+) & INVX (-) & INVX (+) & INVX (-) & INVX (+) \\
\hline Control variables & - & - & - & - & - & - \\
\hline Partnership structure & -0.009 & 0.000 & 0.035 & 0.056 & -0.140 & 0.088 \\
$\begin{array}{c}\text { Partnership year } \\
\text { Recontract likelihood } \\
\text { Firm size }\end{array}$ & 0.043 & -0.031 & 0.012 & 0.076 & -0.146 & -0.007 \\
Main effect & -0.077 & -0.054 & $0.186^{* *}$ & -0.003 & 0.113 & 0.044 \\
\hline Commitment (COMM) & -0.160 & -0.090 & -0.124 & $-0.286^{* * *}$ & $-0.195^{*}$ & -0.182 \\
\hline Moderator & - & - & - & - & - & - \\
\hline Investment-oriented & -0.313 & -0.252 & -0.252 & -0.156 & -0.193 & -0.375 \\
partnership (IPART) & - & - & -0.273 & 0.068 & -0.019 & -0.375 \\
\hline Interaction terms & - & - & - & - & - \\
\hline IPART $\times$ COMM & 0.596 & $0.988^{* *}$ & 0.512 & $0.715^{*}$ & 0.605 & 0.919 \\
\hline NOTE: the main table contains unstandardized coefficients; ${ }^{*} p<0.10 ; * * 0.05 ; * * *<0.01$.
\end{tabular}

Based on a supplementary analysis of two-way interaction effects, as shown in Figure 3, we could further observe the level of commitment and that of investment exchange gap based on partnership structure types. Two-way interaction effects are useful for visually identifying the direction and extent of the moderating role [27].

We firstly observed that, regardless of the investment exchange level, investment exchange positively moderated the relationship between commitment and firm performance. This finding indicates that, regardless of whether investment exchange is negative or positive, the presence of an investment exchange relationship enhances the effectiveness of commitment. This finding is aligned with the regression results in the case of innovation performance and operational performance. Specifically, for partnership structure B, in which the respondent firm is a buyer and the partnership firm is a supplier, the negative investment exchange level depicted higher levels of all three types of performance: operational, innovation, and financial. A possible explanation for this finding is that a buyer firm that invests relatively more in a partnership than its suppliers expects better firm performance than buyer firms that invest relatively less. The nature of the exchange relationship can be partly explained by relationship-specific assets, which are resources that both a buyer and a supplier allocate to the relationship, such as machinery and systems $[4,69]$. Recurring collaborations that build the basis for such relationship-specific investments are expected to enable buyer firms to accumulate knowledge about suppliers, which is then utilized to predict suppliers' transactional behavior [4]. Consequently, Um and Kim [4] concluded that, when there is genuine collaboration signaling high mutual understanding of the partnership, the buyer firm undertakes collaborative activities, such as incentive alignment and resource sharing, to positively increase its transaction cost advantage. In addition to existing findings in the literature that a relation- or partner-specific investment positively moderates commitment and firm performance, we posit that the extent of investment level also drives higher firm performance, even if the firm's absolute investment is larger than the supplier's investment.

The most visually unstandardized interaction effects were shown for the moderating role of investment exchange on the commitment-financial performance relationships, as shown in Figure 3 (A3, B3, C3). While the regression results showed an insignificant effect of the interaction term on firm performance, we further observed and verified that the interactivities had different results based on partnership structure types. For partnership structure B, the negative investment exchange level depicted a greater interaction effect with commitment on firm performance. However, for structure $C$, while both the positive and negative effect had a relatively similar level of interaction role, the performance levels showed a significant scale of difference. For structure $C$, positive investment 
exchange level is strictly necessary for better financial performance, while, for other partnership structures, it might not be necessary. This finding, to a certain extent, is consistent with the view of Oh et al. [70], who argued that external (partnership) collaboration makes a greater contribution to financial performance. In our case, relational investment in terms of resources and time-accompanied by high levels of commitment-affects financial performance from the supplier's perspective.
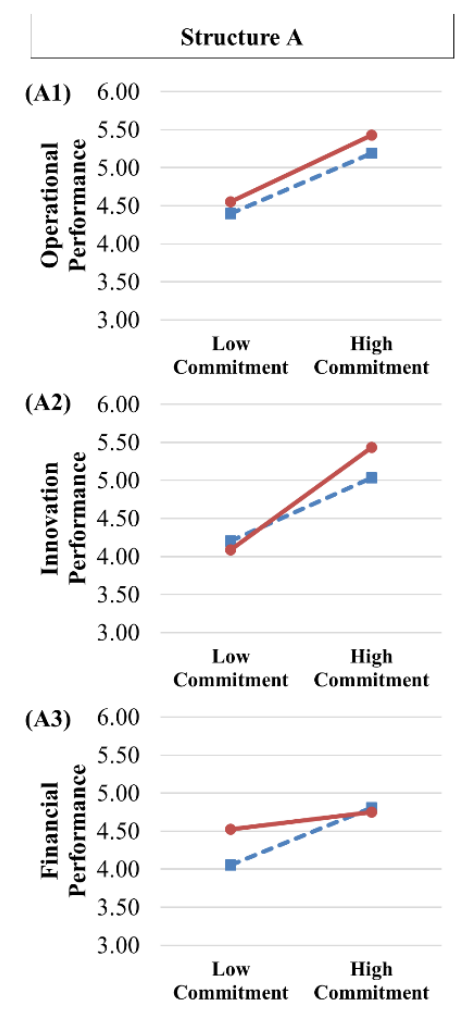

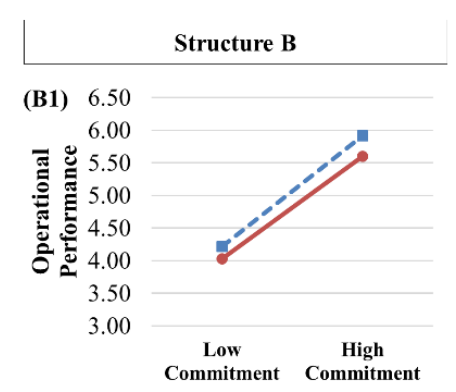

(B2) 6.00

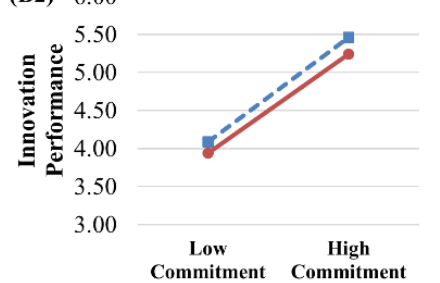

(B3) 6.00

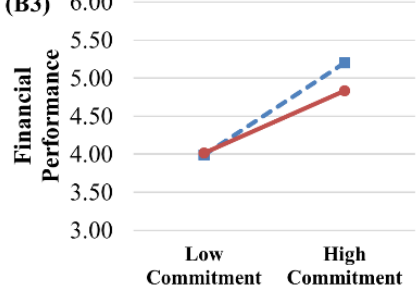

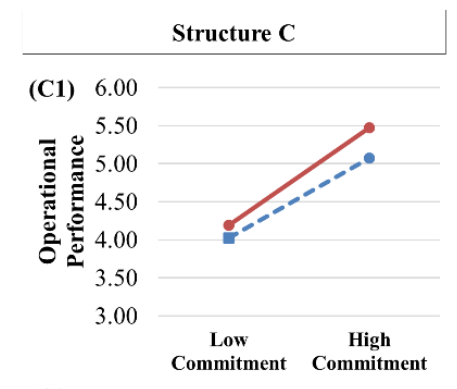

(C2) 6.00

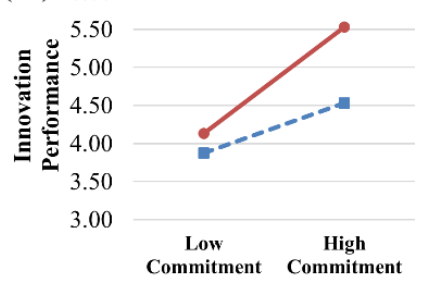

(C3) 6.00

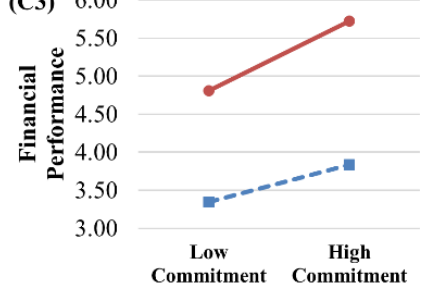

$\ldots . . . . . . \quad$ Negative Investment Exchange $\longrightarrow$ Positive Investment Exchange

Figure 3. Commitment and firm performance in negative/positive investment exchange environments.

\section{Discussion}

The objectives of this study were to examine how to sustain an SC collaborative partnership, i.e., how partnership orientation motivates partnership commitment and, in turn, how this relationship enhances firm performance, from the supplier, buyer, and parallel-aligned firms' perspectives. This study additionally investigated the moderating role of the commitment-investment exchange relationship on the hypothesized relationships.

Following previous research, this study's findings are expected to expand understanding of (i) supply chain collaboration through the lens of partnership orientation, (ii) relation exchange attribute and commitment-based performance outcomes by partnership structure types, and (iii) firm performance management based on the interaction effect of commitment and firms' relative investment exchange level. The proposed partnership-based performance improvement model may help both researchers and practitioners gain a deeper understanding of the appropriate partnership orientation for the desired level of sustainable commitment and firm performance.

The research identified partnership orientation as two key antecedents of partnership commitment. Partnership orientation was examined based on two dimensions: investment and contractual. Investment-oriented partnership was defined in the study using indicators to quantify the level of resource and time investment made as collaborative efforts, while contractual-oriented partnership was represented by the level of official and legal details that enforce and ensure a partner's involvement. As hypothesized, the presence of either investment- or contractual-based partnership 
orientation positively contributes to partnership commitment. Firstly, the finding that both investment- and contract-oriented partnerships are positively associated with commitment from the perspectives of parallel-aligned and buyer firms (partnership structures A and B) is consistent with the existing empirical evidence. Relation-specific investment-driven partnership characteristics enable interconnected firms to (i) undertake long-term planning based on mutual capital expenditure [33], (ii) create effective strategic partnership value [34], (iii) reinforce support for involved partners [35], and (iv) participate in collaborative recycling management as sustainability practice [11]. Investment-oriented partnership also contributes to specific development of partnership commitment through bilateral resource dedication from both the supplier and buyer firms, which effectively increases partnership commitment. Specifically, because buying firms utilize outsourcing strategy to focus on their own core competencies while receiving non-core services from suppliers [40], we argue that partnership structures A and B benefit the most in terms of gaining competitive advantage through investment-oriented partnership.

Secondly, for the supplier firm (partnership structure C), this study verified that only contract-oriented partnership is positively associated with partnership commitment, whereas investment-oriented partnership had an insignificant result. This result supports previous findings that the inter-firm governance mechanism is emphasized for partnership stabilization in anticipation of concerns about opportunism and uncertainties [71]. From the supplier firm's perspective, both the alleviation of potential opportunistic behavior of an exchange partner and the development of reliability between partner firms are vital [39,72]. Earlier studies provided support for the importance of establishing contracting norms and shared expectations among business partners for inter-firm behavioral regulation [40]. Specifically, the authors advocated a contract-based transactional mechanism for effective minimization of the outcome of uncertainties through legal rights and economic incentives.

This study verified the direct association between partnership commitment and firm performance types for different types of partnership structures. Firstly, regardless of the partnership structural relationships, a high level of commitment leads to high levels of innovation performance and operational performance. This finding heightens the importance of the partnership commitment-building process to yield desirable innovation performance, as well as to increase operational performance and financial performance. Sustainable innovation cannot be driven by a sole firm, but a collective knowledge of market characteristics can be driven by interconnected firms [17]. Successful green product innovation can increase end-customers' interests in cost and environmental protection, thereby strengthening the firm's performance $[18,29]$ Highly innovative firms have the advantage of quickly identifying and seizing new market opportunities through close working relationships with interconnected partners [40]. Previous studies strongly indicate the importance of commitment in collaboration relationship, which determines the level of risk of opportunism and information sharing in new product development [40] and operation, planning and control processes, and performance [47]. Secondly, while partnership commitment does not statistically influence financial performance from the perspectives of both parallel-aligned and buyer firms, the results indicated a negative association from the supplier firm's perspective. We argue that, from this perspective, an excessive level of commitment leads to financial sacrifice as a trade-off for the development of a social relationship. A high level of partnership commitment may merely depict a sole local-level management decision rather than a collective decision by participating firms, thereby disregarding both short- and long-term financial outcomes [53]. To sustain an SC collaborative partnership and its commitment level, a careful evaluation of the bilateral exchange relationship based on mutual interest is required. Thus, sustainable commitment is a distinctive attribute, as it is developed only when both firms engage in activities through cooperative behavior [73].

In addition to the abovementioned direct effects, this study linked the investment-based exchange relationship and collaboration literature for a further examination of changes in firm performance. By proposing a partnership-based performance improvement model, this study aimed to improve 
understanding of the role of partnership structure type in the supply chain context. The investment exchange level is operationalized based on the difference between a respondent firm's level of investment and its partner firm's level of investment. In conclusion, four different interactivity terms were developed: low commitment and negative investment exchange, low commitment and positive investment exchange, high commitment and negative investment exchange, and high commitment and high investment exchange. These interactivity groups were utilized to verify the moderating role in firm performance increases. The findings displayed in Table 6 and Figure 3 indicate that (i) investment exchange level moderates the relationship between commitment and innovation and operational performance regardless of partnership structure type, (ii) negative investment exchange instead signals higher firm performance from the buyer firm's perspective, and (iii) positive investment exchange is strictly necessary for financial performance from the supplier firm's perspective. This finding is consistent with previous findings that buyer firms capitalize on supplier firms' competencies and gain significant benefits from the corresponding inter-firm relationship [40], and that supplier firms' performance is negatively affected by an excessive production-information exchange relationship when there is no credible commitment from the buyer firm [73]. From a sustainability management perspective, Luzzini et al. [50] addressed an under-explored investigation of a commitment-driven performance improvement measurement. Their results provided a strong support for the link between commitment in sustainble practice, collaborative capabilities, and overall performance (environmental, social, cost). Simliarly, we argue that the mutual commitment from both buyer and supplier firms is a precondition for overall performance improvement.

In addition to the theoretical contributions of this study, practical implications can be deduced. The proposed model development and empirical results can help managers plan for strategic partnership management for a desired level of innovation, operational, and financial performance. While supply chain collaboration is predominantly emphasized as a relationship orientation primarily for long-term and multi-faceted relationships [9], it must be accompanied by a complementary role for legal contracts and firm rules. Partnership development based on both investment exchange-based relationships and formal agreement-based contractual relationships are likely to strengthen overall partnership commitment from the perspectives of parallel-aligned, supplier, and buyer firms. Moreover, in the context of innovation, partnership commitment is a strong behavioral antecedent for overall improvement in sustainable partnership-driven innovative activities, which in turn strengthens operational performance and financial performance. A high level of partnership commitment can take advantage of network externalities and critical mass [44], thereby spreading innovation and its related performance improvements within the entire supply network.

Some limitations and future avenues should be mentioned. Firstly, the national context potentially limits the generalizability of the findings; therefore, this study should be extended to other countries and include other industries prior to applying our findings in other contexts. Secondly, the measurement indicators of constructs were chosen from literature reviews, and future studies should rigorously select for comprehensiveness. Thirdly, although a single respondent is frequently applied to partnership management research, it lacks full representation of a firm's strategic perspective. Thus, future research may utilize multiple source respondents of a single firm to improve the representativeness of firm's strategic positioning. This research may be perceived as an iterative process and would benefit from further empirical research based on a replicate model [74]. Future research should consider investigating the role of market dynamism in existing versus new markets. A more complete picture of the exchange relationships driving firm performance can be created by measuring the partnership commitment level from both sides of the buyer-supplier dyad. Lastly, future research should also carry out a longitudinal study to capture the varying effects of constructs using different time horizons.

Author Contributions: All authors contributed to the discussions and design of the framework. All authors conceived, developed, and analyzed the research model. N.S. and S.P. wrote the manuscript. S.H.P. and S.P. contributed materials and analysis tools. All authors read and approved the final manuscript. 
Acknowledgments: The authors thank the Institute of Management Research at Seoul National University for supporting this research.

Conflicts of Interest: The authors declare no conflict of interest.

\section{References}

1. Swierczek, A. The impact of supply chain integration on the "snowball effect" in the transmission of disruptions: An empirical evaluation of the model. Int. J. Prod. Econ. 2014, 157, 89-104. [CrossRef]

2. Wichmann, B.K.; Kaufmann, L. Social network analysis in supply chain management research. Int. J. Phys. Distrib. Logist. Manag. 2016, 46, 740-762. [CrossRef]

3. Cao, M.; Zhang, Q. Supply chain collaboration: impact on collaborative advantage and firm performance. J. Oper. Manag. 2011, 29, 163-180. [CrossRef]

4. Um, K.-H.; Kim, S.-M. The effects of supply chain collaboration on performance and transaction cost advantage: The moderation and nonlinear effects of governance mechanisms. Int. J. Prod. Econ. 2018, 1-15. [CrossRef]

5. Barnes, J.; Liao, Y. The effect of individual, network, and collaborative competencies on the supply chain management system. Int. J. Prod. Econ. 2012, 140, 888-899. [CrossRef]

6. Ghadimi, P.; Ghassemi Toosi, F.; Heavey, C. A multi-agent systems approach for sustainable supplier selection and order allocation in a partnership supply chain. Eur. J. Oper. Res. 2018, 269, 286-301. [CrossRef]

7. Hariga, M.; As'ad, R.; Khan, Z. Manufacturing-remanufacturing policies for a centralized two stage supply chain under consignment stock partnership. Int. J. Prod. Econ. 2017, 183, 362-374. [CrossRef]

8. Sheu, C.; Yen, H.J.R.; Chae, B. Determinants of supplier-retailer collaboration: Evidence from an international study. Int. J. Oper. Prod. Manag. 2006, 26, 24-49. [CrossRef]

9. Zhang, Q.; Cao, M. Exploring antecedents of supply chain collaboration: Effects of culture and interorganizational system appropriation. Int. J. Prod. Econ. 2018, 195, 146-157. [CrossRef]

10. Savic, M.; Djordjevic, P.; Milosevic, I.; Mihajlovic, I.; Zivkovic, Z. Assessment of the ISO 9001 functioning on an example of relations with suppliers development: empirical study for transitional economy conditions. Total Qual. Manag. Bus. Excell. 2017, 28, 1285-1306. [CrossRef]

11. Peng, B.; Tu, Y.; Wei, G. Governance of electronic waste recycling based on social capital embeddedness theory. J. Clean. Prod. 2018, 187, 29-36. [CrossRef]

12. Villena, V.H.; Revilla, E.; Choi, T.Y. The dark side of buyer-supplier relationships: a social capital perspective. J. Oper. Manag. 2011, 29, 561-576. [CrossRef]

13. Gil-Saura, I.; Frasquet-Deltoro, M.; Cervera-Taulet, A. The value of B2B relationships. Ind. Manag. Data Syst. 2009, 109, 593-609. [CrossRef]

14. Vanpoucke, E.; Vereecke, A. The predictive value of behavioural characteristics on the success of strategic alliances. Int. J. Prod. Res. 2010, 48, 6715-6738. [CrossRef]

15. Boons, F.; Lüdeke-Freund, F. Business models for sustainable innovation: State-of-the-art and steps towards a research agenda. J. Clean. Prod. 2013, 45, 9-19. [CrossRef]

16. Doganova, L.; Eyquem-Renault, M. What do business models do?. Innovation devices in technology entrepreneurship. Res. Policy 2009, 38, 1559-1570. [CrossRef]

17. Lin, R.J.; Tan, K.H.; Geng, Y. Market demand, green product innovation, and firm performance: Evidence from Vietnam motorcycle industry. J. Clean. Prod. 2013, 40, 101-107. [CrossRef]

18. Kushwaha, G.S.; Sharma, N.K. Green initiatives: A step towards sustainable development and firm's performance in the automobile industry. J. Clean. Prod. 2016, 121, 116-129. [CrossRef]

19. Son, B.G.; Kocabasoglu-Hillmer, C.; Roden, S. A dyadic perspective on retailer-supplier relationships through the lens of social capital. Int. J. Prod. Econ. 2016, 178, 120-131. [CrossRef]

20. Nahapiet, J.; Ghoshal, S. Social Capital, Intellectual Capital, and the Organizational Advantage. Acad. Manag. Rev. 1998, 23, 242. [CrossRef]

21. Krause, D.R.; Handfield, R.B.; Tyler, B.B. The relationships between supplier development, commitment, social capital accumulation and performance improvement. J. Oper. Manag. 2007, 25, 528-545. [CrossRef]

22. Friday, D.; Ryan, S.; Sridharan, R.; Collins, D. Collaborative risk management: a systematic literature review. Int. J. Phys. Distrib. Logist. Manag. 2018. [CrossRef] 
23. Esfahbodi, A.; Zhang, Y.; Watson, G. Sustainable supply chain management in emerging economies: Trade-offs between environmental and cost performance. Int. J. Prod. Econ. 2016, 181, 350-366. [CrossRef]

24. Hillman, A.J.; Withers, M.C.; Collins, B.J. Resource dependence theory: A review. J. Manag. 2009, 35, 1404-1427. [CrossRef]

25. Dyer, J.H.; Nobeoka, K. Creating and managing a high-performance knowledge-sharing network: the Toyota case. Strateg. Manag. J. 2000, 21, 345-367. [CrossRef]

26. Dyer, J.H.; Singh, H. The relational view: Cooperative strategy and sources of interorganizational competitive advantage. Acad. Manag. Rev. 1998, 23, 660-679. [CrossRef]

27. Chavez, R.; Yu, W.; Jacobs, M.; Fynes, B.; Wiengarten, F.; Lecuna, A. Internal lean practices and performance: The role of technological turbulence. Int. J. Prod. Econ. 2015, 160, 157-171. [CrossRef]

28. Pomponi, F.; Fratocchi, L.; Tafuri, S.R.; Rossi Tafuri, S. Trust development and horizontal collaboration in logistics: A theory based evolutionary framework. Supply Chain Manag. An Int. J. 2015, 20, 83-97. [CrossRef]

29. Chen, F.W.; Fu, L.W.; Wang, K.; Tsai, S.B.; Su, C.H. The influence of entrepreneurship and social networks on economic growth-From a sustainable innovation perspective. Sustainability 2018, 10, 2510. [CrossRef]

30. Ryall, M.D.; Sampson, R.C. Formal Contracts in the Presence of Relational Enforcement Mechanisms: Evidence from Technology Development Projects. Manage. Sci. 2009, 55, 906-925. [CrossRef]

31. Zhou, K.Z.; Poppo, L. Exchange hazards, relational reliability, and contracts in China: The contingent role of legal enforceability. J. Int. Bus. Stud. 2010, 41, 861-881. [CrossRef]

32. Woolthuis, R.K.; Hillebrand, B.; Nooteboom, B. Trust, contract and relationship development. Organ. Stud. 2005, 26, 813-840. [CrossRef]

33. Ojala, M.; Hallikas, J. Investment decision-making in supplier networks: Management of risk. Int. J. Prod. Econ. 2006, 104, 201-213. [CrossRef]

34. Bensaou, M. Portfolios of buyer-supplier relationships. MIT Sloan Manag. Rev. 1999, 40, 35-36.

35. Zahra, S.A.; Das, S.R. Innovation strategy and financial performance in manufacturing companies: An empirical study. Prod. Oper. Manag. 2009, 2, 15-37. [CrossRef]

36. Lettice, F.; Wyatt, C.; Evans, S. Buyer-supplier partnerships during product design and development in the global automotive sector: Who invests, in what and when? Int. J. Prod. Econ. 2010, 127, 309-319. [CrossRef]

37. Cao, Z.; Lumineau, F. Revisiting the interplay between contractual and relational governance: A qualitative and meta-analytic investigation. J. Oper. Manag. 2014, 33-34, 15-42. [CrossRef]

38. Roehrich, J.; Lewis, M. Procuring complex performance: Implications for exchange governance complexity. Int. J. Oper. Prod. Manag. 2014, 34, 221-241. [CrossRef]

39. Morgan, R.M.; Hunt, S.D. The Commitment-Trust Theory of Relationship Marketing. J. Mark. 1994, 58, 20. [CrossRef]

40. Yam, R.C.M.; Chan, C. Knowledge sharing, commitment and opportunism in new product development. Int. J. Oper. Prod. Manag. 2015, 35, 1056-1074. [CrossRef]

41. Teece, D.J.; Pisano, G.; Shuen, A. Dynamic capabilities and strategic management. Strateg. Manag. J. 1997, 18, 509-533. [CrossRef]

42. Hausman, A. Innovativeness among small businesses: Theory and propositions for future research. Ind. Mark. Manag. 2005, 34, 773-782. [CrossRef]

43. Hurley, R.F.; Hult, G.T.M. Innovation, market orientation, and organizational learning: An integration and empirical examination. J. Mark. 1998, 62, 42-54. [CrossRef]

44. Panayides, P.M.; Lun, Y.H.V. The impact of trust on innovativeness and supply chain performance. Int. J. Prod. Econ. 2009, 122, 35-46. [CrossRef]

45. Kleinschmidt, E.J.; De Brentani, U.; Salomo, S. Performance of global new product development programs: A resource-based view. J. Prod. Innov. Manag. 2007, 24, 419-441. [CrossRef]

46. Frambach, R.T.; Schillewaert, N. Organizational innovation adoption: A multi-level framework of determinants and opportunities for future research. J. Bus. Res. 2002, 55, 163-176. [CrossRef]

47. Tsanos, C.S.; Zografos, K.G. The effects of behavioural supply chain relationship antecedents on integration and performance. Supply Chain Manag. Int. J. 2016, 21, 678-693. [CrossRef]

48. Narayandas, D.; Rangan, K.V. Building and Sustaining Buyer-Seller Relationships in Mature Industrial Markets. J. Mark. 2004, 68, 63-77. [CrossRef]

49. Wu, I.L.; Chuang, C.H.; Hsu, C.H. Information sharing and collaborative behaviors in enabling supply chain performance: A social exchange perspective. Int. J. Prod. Econ. 2014, 148, 122-132. [CrossRef] 
50. Luzzini, D.; Brandon-Jones, E.; Brandon-Jones, A.; Spina, G. From sustainability commitment to performance: The role of intra- and inter-firm collaborative capabilities in the upstream supply chain. Int. J. Prod. Econ. 2015, 165, 51-63. [CrossRef]

51. Gimenez, C.; van der Vaart, T.; van Donk, D.P. Supply Chain Integration and Performance: The Moderating Effect of Supply Complexity. Int. J. Oper. Prod. Manag. 2012, 32, 583-610. [CrossRef]

52. Yang, J.; Wang, J.; Wong, C.W.Y.; Lai, K.H. Relational stability and alliance performance in supply chain. Omega 2008, 36, 600-608. [CrossRef]

53. Murmura, F.; Bravi, L.; Palazzi, F. Evaluating companies' commitment to corporate social responsibility: Perceptions of the SA 8000 standard. J. Clean. Prod. 2017, 164, 1406-1418. [CrossRef]

54. Sher, P.J.; Yang, P.Y. The effects of innovative capabilities and R\&D clustering on firm performance: The evidence of Taiwan's semiconductor industry. Technovation 2005, 25, 33-43. [CrossRef]

55. Barney, J.B. Firm Resources and Sustained Competitive Advantage. J. Manag. 1991, 17, 99-120. [CrossRef]

56. Calantone, R.; Dröge, C.; Vickery, S. Investigating the manufacturing-marketing interface in new product development: does context affect the strength of relationships? J. Oper. Manag. 2002, 20, 273-287. [CrossRef]

57. Chen, Z.; Huang, S.; Liu, C.; Min, M.; Zhou, L. Fit between organizational culture and innovation strategy: Implications for innovation performance. Sustainability 2018, 10, 3378. [CrossRef]

58. Damanpour, F. Organizational Innovation: A Meta-Analysis of Effects of Determinants and Moderators. Acad. Manag. J. 1991, 34, 555-590.

59. Shao, B.B.M.; Lin, W.T. Assessing output performance of information technology service industries: Productivity, innovation and catch-up. Int. J. Prod. Econ. 2016, 172, 43-53. [CrossRef]

60. Hult, G.T.M.; Ketchen, D.J. Does market orientation matter?: A test of the relationship between positional advantage and performance. Strateg. Manag. J. 2001, 22, 899-906. [CrossRef]

61. Kwon, I.G.; Suh, T. Trust, commitment and relationships in supply chain management: A path analysis. Supply Chain Manag. Int. J. 2005, 10, 26-33. [CrossRef]

62. Kumar, N.; Scheer, L.K.; Steenkamp, J.-B.E.M. The Effects of Perceived Interdependence on Dealer Attitudes. J. Mark. Res. 1995, 32, 348. [CrossRef]

63. Kim, D.Y. Understanding supplier structural embeddedness: A social network perspective. J. Oper. Manag. 2014, 32, 219-231. [CrossRef]

64. Tomlinson, P.R.; Fai, F.M. The nature of SME co-operation and innovation: A multi-scalar and multi-dimensional analysis. Int. J. Prod. Econ. 2013, 141, 316-326. [CrossRef]

65. Hair, J.F.; Black, W.C.; Babin, B.J.; Anderson, R.E.; Tatham, R.L. Multivariate Data Analysis; Prentice-Hall: Upper Saddle River, NJ, USA, 2006.

66. Brusset, X. Does supply chain visibility enhance agility? Int. J. Prod. Econ. 2016, 171, 46-59. [CrossRef]

67. Bagozzi, R.P.; Yi, Y. On the Evaluation of Structural Equation Models. J. Acad. Mark. Sci. 1988, 16, 74-94. [CrossRef]

68. Fornell, C.; Larcker, D.F. Evaluating structural equation models with unobservable variables and measurement error. J. Mark. Res. 1981, 18, 39-50. [CrossRef]

69. Yan, T.; Nair, A. Structuring Supplier Involvement in New Product Development: A China-U. S. Study. Decis. Sci. 2016, 47, 589-627. [CrossRef]

70. Oh, S.; Yang, H.; Kim, S.W. Managerial capabilities of information technology and firm performance: Role of e-procurement system type. Int. J. Prod. Res. 2014, 52, 4488-4506. [CrossRef]

71. Benton, W.C.; Maloni, M. The influence of power driven buyer/seller relationships on supply chain satisfaction. J. Oper. Manag. 2005, 23, 1-22. [CrossRef]

72. Gundlach, G.T.; Achrol, R.S.; Mentzer, J.T. The Structure of Commitment in Exchange. J. Mark. 1995, 59, 78-92. [CrossRef]

73. Srinivasan, R.; Brush, T.H. Supplier Performance in Vertical Alliances: The Effects of Self-Enforcing Agreements and Enforceable Contracts. Organ. Sci. 2006, 17, 436-452. [CrossRef]

74. Kaynak, H.; Hartley, J.L. Using replication research for just-in-time purchasing construct development. J. Oper. Manag. 2006, 24, 868-892. [CrossRef]

(C) 2019 by the authors. Licensee MDPI, Basel, Switzerland. This article is an open access article distributed under the terms and conditions of the Creative Commons Attribution (CC BY) license (http:/ / creativecommons.org/licenses/by/4.0/). 